\title{
Factors affecting trace element uptake in the black mussel Septifer virgatus
}

\author{
Wen-Xiong Wang*, Robert C.H. Dei \\ Department of Biology, The Hong Kong University of Science and Technology (HKUST), Clear Water Bay, \\ Kowloon, Hong Kong
}

\begin{abstract}
The variability of the influx rates of $\mathrm{Cd}, \mathrm{Cr}(\mathrm{VI})$, Se(TV), and $\mathrm{Zn}$ in the black mussel Septifer virgatus from Hong Kong coastal waters was examined under different environmental and biological conditions using the radiotracer technique. The uptake of trace elements generally proceeded linearly over time and a short-term exposure $(4 \mathrm{~h})$ was therefore employed to measure the influx rate of trace elements. The uptake rates were directly proportional to the concentration of trace elements in the dissolved phase. The calculated uptake rate constant was $0.286,0.085,0.031$, and $0.460 \mathrm{lg}^{-1} \mathrm{~d}^{-1}$ for $\mathrm{Cd}$, $\mathrm{Cr}(\mathrm{VI})$, Se(IV), and $\mathrm{Zn}$, respectively. Transport of $\mathrm{Cd}$ and $\mathrm{Zn}$ was primarily a facilitated process that was significantly inhibited by $\mathrm{N}$-ethylmaleimide due to its specific binding with SH-containing ligands. Uptake rates of $\mathrm{Cd}$ and $\mathrm{Zn}$ were closely coupled, whereas no relationship of their uptake with Cr(VI) or Se(IV) uptake was found. Uptake of Cr(VI) and Se(IV) was decoupled, indicating that they were transported via different pathways into the mussels. The Ca channel was not involved in the transport of all trace elements. A decrease in salinity greatly enhanced the influx of all 4 trace elements. Changes in metal speciation and $\mathrm{Ca}$ concentration were not responsible for the underlying effects of salinity. The allometric scaling of $\mathrm{Cr}(\mathrm{VI})$ and Se(IV) uptake was comparable to the allometric scaling of the mussels' filtration rate, suggesting that gill surface area may determine their uptake rate. The uptake of $\mathrm{Cr}$ (VI) and Se(IV) may simply be predicted based on the measurements of the mussel's filtration rate. For Cd and $\mathrm{Zn}$, the allometry of metal uptake may also be controlled by other processes such as SH-containing ligands available for metal binding
\end{abstract}

KEY WORDS: Cadmium · Chromium - Metals · Selenium - Septifer virgatus $\cdot$ Zinc $\cdot$ Uptake

\section{INTRODUCTION}

Marine bivalves, most notably the blue mussels Mytilus edulis, have been employed extensively as biomonitors of coastal contamination largely because of their easy assessability and faithful responses to ambient bioavailable metal levels. Bivalves are also an important component in many benthic ecosystems and may play a considerable role in the biogeochemical cycling of trace elements in coastal waters. Numerous experimental studies have therefore addressed the effects of various environmental and biological factors on metal uptake in bivalves, including temperature, salinity, metal concentration and speciation, season, and body size (e.g. Fischer 1986, Borchardt et al. 1988, Phillips \& Rainbow 1993, Langston \& Spence 1995).

·E-mail: wwang@ust.hk
However, the mechanisms of metal transport in aquatic invertebrates are less well studied. Simkiss \& Taylor (1989) propose several possible pathways of metal transport such as passive diffusion, facilitated transport, active transport, lipid permeation, channel transport, and pinocytosis. The applicability of each pathway to specific animals and metals and the relative importance of different pathways are relatively unknown (Rainbow 1997). It is well known that both geochemical processes (e.g. free metal ion concentration, dissolved organic matter) and biological processes affect metal uptake in aquatic animals. Geochemical controls such as the free metal ion speciation can be readily incorporated into the models of metal transport across the biological membranes (reviewed in Campbell 1995). Fewer experimental studies have however considered the controls of the physiological processes on metal uptake in aquatic invertebrates. 
Recently, considerable interest has been generated regarding metal trophic transfer in aquatic invertebrates, which has been demonstrated to be a significant source for metal uptake (reviewed in Fisher \& Reinfelder 1995, Reinfelder et al. 1998, Wang \& Fisher in press). Metal assimilation efficiency from ingested food particles, an index quantifying metal bioavailability from particulate phase, can now be routinely measured under different ecological conditions (Wang \& Fisher 1999a). However, metal absorption efficiency from the dissolved phase, an index quantifying metal bioavailability from the dissolved phase and analogous to metal assimilation efficiency, is not well studied. This is primarily due to the difficulty in realistically quantifying metal absorption efficiency and a lack of mechanistic understanding of this physiological parameter. Recent measurements on metal uptake rates from the dissolved phase rely on a short-term exposure to overcome potential problems associated with longterm uptake experiments (e.g. Luoma et al. 1992, Wang et al. 1996, Lee et al. 1998). With a short-term exposure, the chemistry of the medium can be well defined without being notably confounded by the bivalve's metabolites. In addition, the animal physiology (e.g. pumping or filtration rate) can be reasonably well maintained within the short-term exposure period. Consequently, the effects of different environmental and biological conditions on metal influx can be quantitatively assessed. Several recent studies have quantified the influx rate of metals into bivalves as a function of ambient metal concentrations, dissolved organic carbon concentration, salinity, and body size (Luoma et al. 1992, Wang et al. 1996, Wang \& Fisher 1997 a, Lee et al. 1998, Roditi \& Fisher in press). The uptake rate constant based on these flux measurements is then incorporated into a bioenergetic-based kinetic model to predict the bioaccumulation and to separate the exposure pathways of metals in bivalves (Luoma \& Fisher 1997, Wang \& Fisher in press). In these studies, large interspecific and intraspecific variations in metal uptake rates have been found, but the processes responsible for the variability of metal uptake are not well defined.

In this study, we examine the influence of several important physiological and environmental factors (metal concentration in ambient water, salinity, calcium concentration, body size) on metal uptake in the black mussel Septifer virgatus. S. virgatus is abundant in the intertidal rocky shores in Hong Kong coastal waters. It has been previously considered as a biomonitor of coastal contamination in Hong Kong waters (Phillips \& Yim 1981). The physiology and the processes governing metal accumulation in this species are not known, but are necessary for assessing the usefulness of this species as a potential biomonitor in Hong Kong coastal waters for diverse metals. We used selected blockers to examine the mechanisms of metal transport in the mussels (e.g. facilitated transport and $\mathrm{Ca}$ channel transport). A previous study showed that the Ca channel may be involved in the transport of $\mathrm{Ag}$ and $\mathrm{Zn}$ in the mussel Mytilus edulis, but not in the clam Macoma balthica (Wang \& Fisher 1999b). Four metals [Cd, Cr(VI), Se(IV), and Zn] were considered in this study. Among the metals, $\mathrm{Cd}$ and $\mathrm{Zn}$ are soft (or Class B) metals that prefer binding with $\mathrm{S}$ ligands than to $\mathrm{N}$ or $\mathrm{O}$ ligands. $\mathrm{Cr}$ in natural seawater exists as both cationic chromic [Cr(III)] and anionic chromate [Cr(VI)], whereas Se exists as Se(VI) (selenate), Se(IV) (selenite), Se(0) (elemental Se), and organoselenium (Cutter 1989, AbuSaba \& Flegal 1995). We only quantified the uptake of Cr(VI) and Se(IV), primarily because of their dominance in the aqueous phase and their higher bioavailability to aquatic organisms than the other redox species (Riedel et al. 1996, Wang et al. 1997).

\section{MATERIALS AND METHODS}

Mussels Septifer virgatus of 2.0 to $2.5 \mathrm{~cm}$ shell length were collected from the intertidal rocky shore in Clear Water Bay, Hong Kong, between August and October 1998. After the mussels were brought back to the laboratory, they were cleaned of epibionts and maintained in the laboratory for about 1 wk prior to radioactive uptake experiments. Mussels were acclimated at $18^{\circ} \mathrm{C}$ and $30 \mathrm{ppt}$, and fed diatoms Thalassiosira pseudonana (Clone $3 \mathrm{H}$ ). All experiments were conducted at $18^{\circ} \mathrm{C}$ and $30 \mathrm{ppt}$ (except the salinity experiment described below).

General experimental protocol. The general protocol to measure the influx rate of metals in mussels involves a short-term exposure ( $4 \mathrm{~h}$ ) to minimize metal efflux, complexation with the animal's metabolites, and a decline in the mussel's filtering activity. The radioisotopes ${ }^{109} \mathrm{Cd}$ (in $0.1 \mathrm{~N} \mathrm{HCl}$ ), ${ }^{51} \mathrm{Cr}(\mathrm{VI})$ (in $0.1 \mathrm{~N}$ $\mathrm{HCl}$ ), ${ }^{75} \mathrm{Se}(\mathrm{lV})$ (as selenite in distilled water), and ${ }^{65} \mathrm{Zn}$ (in $0.1 \mathrm{~N} \mathrm{HCl}$ ) were used in all experiments to determine the influx rate of metals in mussels. The ${ }^{75} \mathrm{Se}$ was obtained from Amersham and the other radioisotopes were from New England Nuclear. Radioisotope additions were $1.85 \mathrm{kBq} \mathrm{I}^{-1}(0.22 \mathrm{nM})$ for ${ }^{109} \mathrm{Cd}, 14.8 \mathrm{kBq} \mathrm{l}^{-1}$ $(0.03 \mathrm{nM})$ for ${ }^{51} \mathrm{Cr}, 7.4 \mathrm{kBq} \mathrm{l^{-1 }}(0.19 \mathrm{nM})$ for ${ }^{75} \mathrm{Se}$, and $3.7 \mathrm{kBq} \mathrm{l^{-1 }}(0.44 \mathrm{nM})$ for ${ }^{65} \mathrm{Zn}$. In all experiments, radioisotopes were first equilibrated with stable metals for about $12 \mathrm{~h}$ (in $0.2 \mu \mathrm{m}$ filtered seawater) before uptake measurements were made. In this study, dissolved metal was defined as any metal passing through the $0.2 \mu \mathrm{m}$ membrane. With the exception of measuring metal influx rate at different ambient metal concentrations, the influx rates were measured at concen- 
trations of $18 \mathrm{nM}$ for Cd, $38 \mathrm{nM}$ for Cr(VI), $25 \mathrm{nM}$ for Se(IV), and $77 \mathrm{nM}$ for $\mathrm{Zn}$. All radioisotopes and their respective stable metals were added simultaneously. Because radioisotopes were carried in acidic solutions, microliter amounts of $0.1 \mathrm{~N} \mathrm{NaOH}$ were added in to filtered seawater before the addition of radioisotopes to maintain the $\mathrm{pH}$ at 8.0. The multi-labeling technique minimized the biological variability associated with different experiments, therefore any variation among metals was due to differences of chemical behavior in the animals

In order to confirm that the influx rate measured over a short-term exposure period ( $4 \mathrm{~h}$ ) was representative of the actual uptake rate, we first conducted an experiment to test the time-dependence of metal uptake. Mussels were individually exposed to metals (both stable and radioisotopes) in the dissolved phase, in $150 \mathrm{ml}$ $0.2 \mu \mathrm{m}$ filtered seawater. At time intervals $(2 \mathrm{~h}), 3$ individual mussels were removed from 3 beakers and rinsed by placing them in non-radioactive seawater for $10 \mathrm{~min}$ before dissection. Radioactivity in the soft tissues and in the shells was then determined. The remaining individuals were placed in new batches of water containing both radioisotopes and stable metals. This experiment lasted for $8 \mathrm{~h}$ and the results confirmed that metal uptake proceeded linearly over time (see 'Results'). In all subsequent experiments, we employed a $4 \mathrm{~h}$ exposure to determine metal influx rate, which was necessary to obtain a measurable amount of radioactivity in the soft tissues of mussels while keeping the amount of added radioisotopes to a minimal level.

To measure the influx rates, mussels were continuously fed with diatoms before the dissolved uptake experiments and placed individually in $500 \mathrm{ml}$ of $0.2 \mu \mathrm{m}$ filtered seawater containing both stable and radioactive metals. There were 8 replicates for each experimental treatment. The water was stirred gently every hour to reduce gradients in metal concentrations within the beakers. After $4 \mathrm{~h}$ exposure, mussels were removed from individual beakers and placed into $200 \mathrm{ml}$ non-radioactive seawater for $10 \mathrm{~min}$, allowing any weakly absorbed metals to desorb from the soft tissues. The tissues were then dissected (excluding pallial fluid) and their radioactivity was counted, after which the tissues were dried at $80^{\circ} \mathrm{C}$ overnight and weighed. In this study, tissues are reported as dry weight unit. Aliquots of water were also filtered through $0.2 \mu \mathrm{m}$ membranes to determine the fraction of radioisotopes associated with particles (>0.2 $\mu \mathrm{m})$ after exposure. Results showed that a negligible amount $(<1 \%)$ of the metal was retained on the $0.2 \mu \mathrm{m}$ membranes, thus metal uptake during the exposure period reflected uptake from the dissolved phase. The influx rate was then calculated as:

$$
I_{w}=A_{\text {tissues }} /(S A \times W \times t)
$$

where $I_{\mathrm{w}}$ is the influx rate of metals in mussels $\left(\mathrm{ng} \mathrm{g}^{-1}\right.$ $\mathrm{h}^{-1}$ ), $A_{\text {tissues }}$ is the radioactivity in the soft tissues after exposure, $S A$ is the specific activity of metal in seawater, $W$ is the dry weight of soft tissue $(g)$, and $t$ is the duration of exposure ( $4 \mathrm{~h})$.

Metal influx rates at different ambient concentrations. Influx rates were measured at different ambient concentrations. The lowest concentrations were about 2 to 50 times higher than the typical background concentrations in coastal waters (Bruland 1983, Flegal et al. 1991). The background metal concentrations were not measured in this study. Thus, the experimental concentrations were $4.5,17.8,89.3,446 \mathrm{nM}$ for $\mathrm{Cd}$, $9.6,38.5,192,961 \mathrm{nM}$ for $\mathrm{Cr}(\mathrm{VI}), 6.3,25.3,126,633 \mathrm{nM}$ for Se(IV), and 15.4, 76.9, 308, $1538 \mathrm{nM}$ for $\mathrm{Zn}$

Effects of salinity on trace element influx. Mussels (collected from a salinity of $30 \mathrm{ppt}$ ) were acclimated to a range of salinity $(15,20,25$, and 34 ppt) for a period of $2 \mathrm{wk}$, during which they were fed with diatom food. At the lowest salinity (15 ppt), mussels were first acclimated to 20 ppt for $4 \mathrm{~d}$, followed by a $10 \mathrm{~d}$ acclimation at 15 ppt. The range of salinity covered the typical salinity in Hong Kong coastal waters. Lower salinity seawater was prepared by diluting the $34 \mathrm{ppt}$ seawater with Nanopure $(18 \mathrm{~m} \Omega \mathrm{cm})$ distilled water. The $\mathrm{pH}$ was maintained at 8.0 for all salinity treatments.

Effects of calcium concentration on trace element influx. Trace element influx rates were measured at different ambient calcium concentrations but at the same salinity ( $30 \mathrm{ppt}$ ). The experimental Ca concentrations $(4.29,5.72,7.15$, and $9.72 \mathrm{mM})$ corresponded to Ca concentrations found in seawater at 15, 20, 25, and 34 ppt salinity, respectively. Chemically defined seawater was used in this experiment (Blust et al. 1992). The seawater medium (at $30 \mathrm{ppt}, \mathrm{pH} 8.0$ ) contained: $0.32 \mathrm{M} \mathrm{NaCl}, 22.5 \mathrm{mM} \mathrm{Na}_{2} \mathrm{SO}_{4}, 7.3 \mathrm{mM} \mathrm{KCl}, 1.87 \mathrm{mM}$ $\mathrm{NaHCO}_{3}, 42.4 \mathrm{mM} \mathrm{MgCl}$, and $0.34 \mathrm{mM} \mathrm{H}_{3} \mathrm{BO}_{3}$. Nanopure distilled water was used to prepare the seawater medium and the $\mathrm{pH}$ was maintained at 7.8. The water was aerated for $6 \mathrm{~h}$ and then filtered through $0.2 \mu \mathrm{m}$ polycarbonate membranes before the additions of radioisotopes and stable metals.

Effects of the Ca channel and metabolic blockers on trace element influx. To test if the Ca channel and SHbinding ligand were involved in metal transport, the influx of trace elements was determined in the presence of Ca channel blockers (verapamil, lanthanum as $\mathrm{LaCl}_{3}$ ) and a metabolic blocker ( $\mathrm{N}$-ethylmaleimide). The control treatment contained no blocker in the medium. All blockers were obtained from Sigma Chemical Co. and were dissolved in distilled water. Concentrations were $20 \mu \mathrm{M}$ for verapamil, $50 \mu \mathrm{M}$ for $\mathrm{LaCl}_{3}$, and $10 \mu \mathrm{M}$ for $\mathrm{N}$-ethylmaleimide. Mussels were 


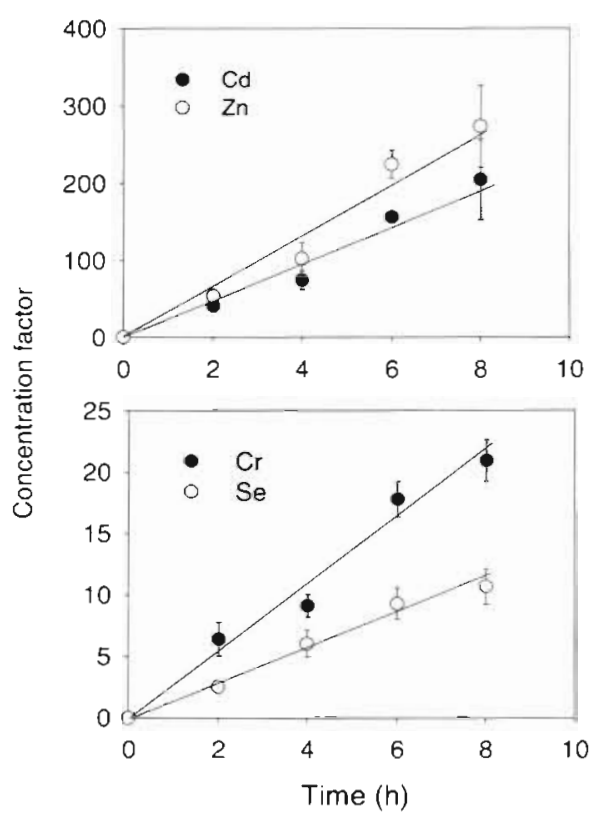

Fig. 1. Septifer virgatus. The calculated concentration factors $\left(\mathrm{kg}^{-1}\right)$ of $\mathrm{Cd}, \mathrm{Cr}(\mathrm{VI}), \mathrm{Se}(\mathrm{IV})$, and $\mathrm{Zn}$ in mussel's soft tissues over time. Mean $\pm \mathrm{SD}(\mathrm{n}=3)$. Concentration factor is the ratio of metal concentration in the mussels ( $\mu \mathrm{g} \mathrm{g}^{-1}$ dry wt) to metal concentration in the dissolved phase $\left(\mu \mathrm{g} \mathrm{I}^{-1}\right)$

pre-exposed to these blockers for $1 \mathrm{~h}$ in unlabeled seawater before the influx measurements.

Effects of EDTA on trace element influx. Trace element influx rates were determined in the presence of EDTA at 0.5 and $5 \mu \mathrm{M}$, respectively. The other conditions were similar to those described above.

Effects of body size on trace element influx. Different body sizes of mussels $(0.011$ to $0.384 \mathrm{~g}$ dry tissue weight) were collected from Clear Water Bay, Hong Kong, and acclimated in the laboratory as described above. The influx rates were then determined under similar conditions described above.

Filtration rate of mussels. The filtration rates of different sizes of mussels were measured as described in Wang \& Fisher (1997b) and Widdows et al. (1997). Individual mussels were placed in $1.5 \mathrm{I}$ of $0.2 \mathrm{~m}$ filtered seawater. For the smallest size of mussels, we pooled 3 to 4 individual mussels into each beaker and the mean filtration rate was subsequently calculated. The diatom Thalassiosira pseudonana (Clone $3 \mathrm{H}$ ) was filtered and resuspended in filtered seawater to remove any algal metabolites and nutrient media that can affect the pumping activity of mussels (Ward \& Targett 1989, K. Chan \& W. X. Wang unpubl. data). Diatom cells were added to the feeding beakers at a concentration of 20000 cells ml ${ }^{-1}$ and were kept homogeneous by gentle aeration. An aliquot of $10 \mathrm{ml}$ water sample was taken every $0.5 \mathrm{~h}$ (for a total of $2 \mathrm{~h}$ ) and the cell density was determined by a Coulter Counter. The filtration rate $(F R)$ was then calculated as:

$$
\mathrm{FR}=\left(\ln C_{t}-\ln C_{0}\right) \times \mathrm{Vol} / \mathrm{T}
$$

where $C_{t}$ is the cell density at time $t$ (cells $\mathrm{ml}^{-1}$ ), $C_{0}$ is the cell density at time 0 (cells mll $\left.{ }^{-1}\right), \mathrm{Vol}$ is the volume of water (l), and $T$ is the duration of measurement (h). The individual and weight-specific filtration rates were calculated from the average of 4 consecutive measurements (every $0.5 \mathrm{~h}$ ). At the end of the experiments, mussels were dissected and dried at $80^{\circ} \mathrm{C}$ to measure their dry tissue weights.

Gamma radioactivity measurements. The gamma radioactivity of the mussel's soft tissues and water was measured with a Wallac $1480 \mathrm{NaI}(\mathrm{Tl})$ gamma detector. All measurements were related to appropriate standards and calibrated with spillover. The gamma emission of ${ }^{109} \mathrm{Cd}$ was determined at $22 \mathrm{keV},{ }^{51} \mathrm{Cr}$ at $320 \mathrm{keV}$, of ${ }^{75} \mathrm{Se}$ at $264 \mathrm{keV}$, and of ${ }^{65} \mathrm{Zn}$ at $1115 \mathrm{keV}$. Counting times were adjusted to yield a propagated counting error $<5 \%$.

\section{RESULTS}

Metal uptake from the dissolved phase proceeded linearly over time for all 4 metals examined in this study (Fig. 1). There was no evidence of saturation or equilibrium of metal uptake within the $8 \mathrm{~h}$ exposure period. The concentration factor, calculated as the ratio of radioactivity in the mussel's soft tissues ( $\mathrm{dpm} \mathrm{kg}^{-1}$ dry wt) to metal concentration in the dissolved phase $\left(\mathrm{dpm} \mathrm{^{-1 }}\right)$, was the highest for $\mathrm{Zn}$, followed by $\mathrm{Cd}>$ $\mathrm{Cr}(\mathrm{VI})>\mathrm{Se}(\mathrm{IV})$. The distribution of metals in the shells remained relatively constant throughout the exposure period. A considerable fraction of metals ( 19 to $30 \%$ for Cd, 50 to $53 \%$ for $\mathrm{Cr}(\mathrm{VI}), 38$ to $46 \%$ for Se(IV), and 44 to $49 \%$ for $\mathrm{Zn}$ ) was associated with the shells. In this study, we considered only the metal influx into the mussel's soft tissues; surface adsorption onto the shells was not considered.

There was a linear log-log relationship between the influx rate and metal concentration in the dissolved phase (Fig. 2). The coefficients describing this relationship were close to 1 , indicating that metal influx rate was directly proportional to the metal concentration in the dissolved phase. Thus, the uptake rate constant could be calculated as the $y$ intercept of the log-log regression, and was $0.286,0.085,0.031,0.460 \mathrm{l} \mathrm{g}^{-1} \mathrm{~d}^{-1}$ for $\mathrm{Cd}, \mathrm{Cr}(\mathrm{VI}), \mathrm{Se}(\mathrm{IV})$, and $\mathrm{Zn}$, respectively. The uptake rate constant was the highest for $\mathrm{Zn}$, followed by $\mathrm{Cd}>\mathrm{Cr}(\mathrm{VI})>\mathrm{Se}(\mathrm{IV})$.

The influx rate increased significantly with a decrease in salinity for all metals $(p<0.01$, ANOVA, Fig. 3). When the salinity was reduced from $34 \mathrm{ppt}$ to 


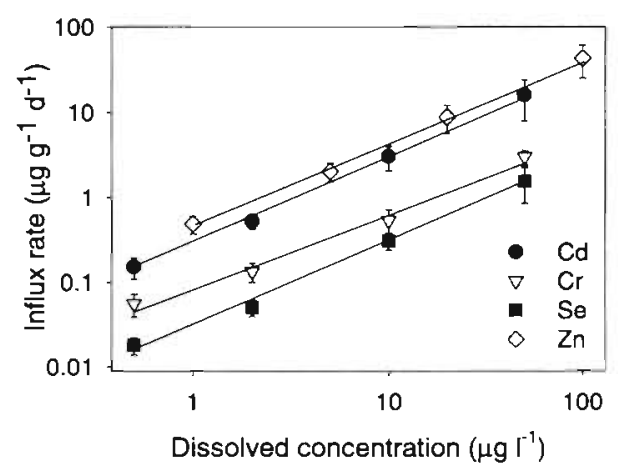

Fig. 2. Septifer virgatus. Metal influx rates in mussels exposed to different concentrations in the dissolved phase. Mean \pm SD $(\mathrm{n}=8$ ). Regressions describing the relationship between metal influx rate $\left(I_{w}, \mu g \mathrm{~g} \mathrm{~g}^{-1}\right.$ dry $\left.w \mathrm{~d}^{-1}\right)$ and metal concentration in the dissolved phase $\left(C_{w}, \mu \mathrm{g} \mathrm{I}^{-1}\right)$ follow: for $\mathrm{Cd}$ : $I_{w}=$ $0.286 C_{\mathrm{w}}{ }^{1022}\left(\mathrm{r}^{2}=0.999\right)$; for $\operatorname{Cr}(\mathrm{VI}): I_{\mathrm{w}}=0.085 C_{\mathrm{w}}{ }^{0.869}\left(\mathrm{r}^{2}=\right.$ $0.988)$; for Se(IV): $I_{\mathrm{w}}=0.031 C_{\mathrm{w}}{ }^{0.986}\left(\mathrm{r}^{2}=0.994\right)$; and for $\mathrm{Zn}$ $I_{w}=0.460 C_{w^{\prime}}{ }^{0.980}\left(r^{2}=0.999\right)$

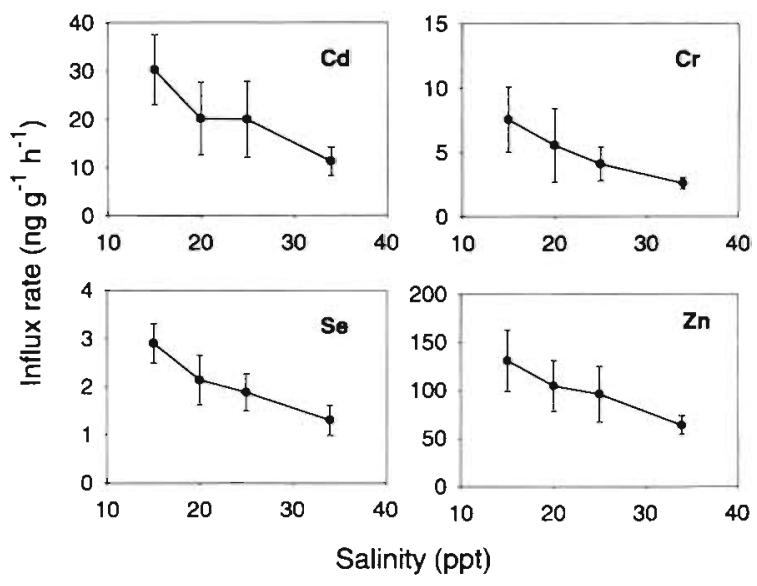

Fig. 3. Septifer virgatus. Metal influx rates in mussels exposed to different salinities. Mean $\pm S D(n=8)$. Regressions describing the linear relationship between influx rate $\left(I_{\mathrm{w}}, \mathrm{ng} \mathrm{g}^{-1} \mathrm{dry}\right.$ wt $\left.\mathrm{h}^{-1}\right)$ and salinity (S) follow: for Cd: $I_{\mathrm{w}}=41.84-0.91 \mathrm{~S}\left(\mathrm{r}^{2}=\right.$ $0.902)$; for $\operatorname{Cr}(\mathrm{VI}): I_{\mathrm{w}}=10.96-0.26 \mathrm{~S}\left(\mathrm{r}^{2}=0.956\right)$; for $\operatorname{Se}(\mathrm{IV})$; $I_{\mathrm{w}}=3.91-0.08 \mathrm{~S}\left(\mathrm{r}^{2}=0.942\right) ;$ and for $\mathrm{Zn}: I_{\mathrm{w}}=177.8-3.4 \mathrm{~S}$ $\left(r^{2}=0.976\right)$

25 and $20 \mathrm{ppt}$, the influx rates increased by 1.4 to 2.1 times for all metals. With a further decrease to $15 \mathrm{ppt}$, the influx rate increased by 2.0 to 2.9 times compared to influx rates measured at $34 \mathrm{ppt}$. The relative magnitude of the change in the influx rate in response to decreasing salinity was comparable among the 4 metals. Variation of calcium concentration in ambient water (while the salinity was maintained constant at $30 \mathrm{ppt}$ ), however, did not influence the metal influx (Fig. 4). The results also indicated that the uptake rate measured in a chemically defined medium was comparable to the uptake rate determined using natural seawater at the same salinity (30 ppt) (Figs. 2
\& 4). Because $\mathrm{Ca}$ concentration did not significantly affect the metal uptake rate, we pooled all experimental individuals to examine the inter-relationships of uptake rates among the 4 metals (Fig. 5). There was a significant relationship between the influx rates of $\mathrm{Cd}$ and $\mathrm{Zn}$, suggesting that their uptake was coupled in the mussels. No significant relationship was found between the other metals.

The influx rates of $\mathrm{Cd}, \mathrm{Cr}(\mathrm{VI})$, and $\mathrm{Zn}$ were not affected in mussels exposed to $2 \mathrm{Ca}$ channel blockers (verapamil and lanthanum), whereas Se(IV) uptake was increased by 5.1 times in mussels exposed to lanthanum (Fig. 6). Ethylmaleimide, which specifically blocked the SH-containing ligands, significantly reduced the uptake of $\mathrm{Cd}$ by $34 \%$ and $\mathrm{Zn}$ by $36 \%$, whereas it did not affect the uptake of $\mathrm{Cr}(\mathrm{VI})$ and Se(IV) (Fig. 7). Similarly, uptake of Cd decreased by 42 and $89 \%$, and uptake of $Z n$ decreased by 86 and $88 \%$, in mussels exposed to 0.5 and $5 \mu \mathrm{M}$ EDTA, respectively

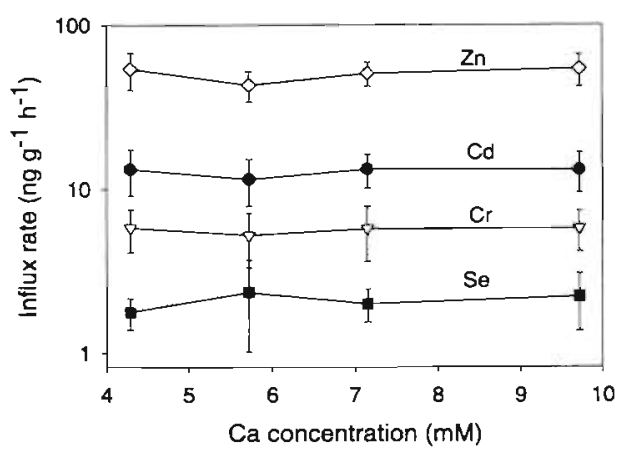

Fig. 4. Septifer virgatus. Metal influx rates in mussels exposed to different ambient calcium concentrations. Mean $\pm \mathrm{SD}$ $(n=8)$
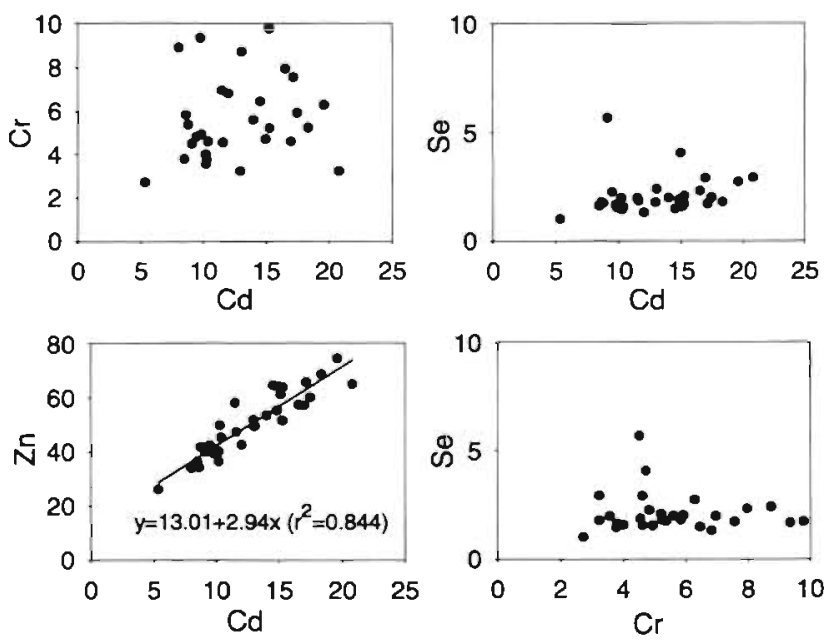

Fig. 5. Septifer virgatus. Inter-relationships of metal influx rates (ng g $\mathrm{g}^{-1}$ dry $\mathrm{wt} \mathrm{h}^{-1}$ ) in mussels. Each data point represents 1 individual mussel 


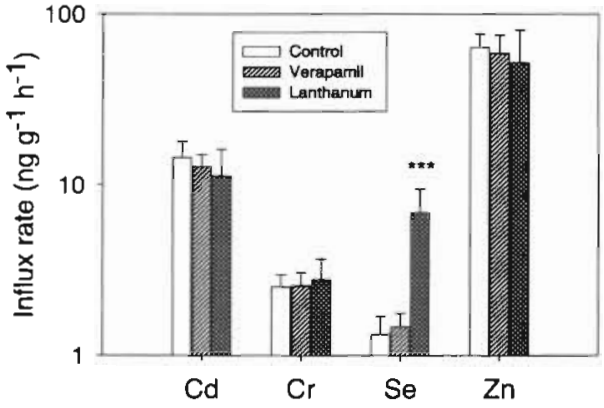

Fig. 6. Septifer virgatus. Metal influx rates in mussels exposed to verapamil and lanthanum. Mean $\pm \mathrm{SD}(\mathrm{n}=8)$. Differences of metal influx rate from controls are statistically significant ( $t$-test) at various $p$ levels as follows: $\cdots p<0.001$

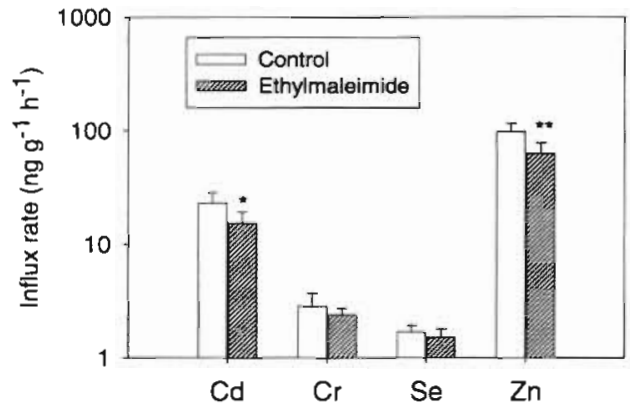

Fig. 7. Septifer virgatus. Metal influx rates in mussels exposed to ethylmaleimide. Mean $\pm S D(n=8)$. Differences of metal influx rate from controls are statistically significant ( $t$-test) at various $p$ levels as follows: " $p<0.05 ; " \cdot p<0.01$

(Fig. 8). Cr(VI) uptake was not influenced by the presence of EDTA, whereas Se(VI) uptake increased by $30 \%$ at $5 \mu \mathrm{M}$ EDTA $(\mathrm{p}<0.05)$

Influx rates of all 4 metals decreased in a power function with increasing body size in mussels (Fig. 9). The allometric coefficients describing such relationships were $-0.537,-0.344,-0.317$, and -0.437 for $\mathrm{Cd}$, $\mathrm{Cr}(\mathrm{VI}), \mathrm{Se}(\mathrm{IV})$, and $\mathrm{Zn}$, respectively. The FR increased whereas the weight-specific filtration rate decreased with increasing body size with a power coefficient of 0.682 and -0.318 , respectively (Fig. 10). The absorption efficiency of metals from the dissolved phase can be calculated by the following equation (Wang et al. 1996):

$$
\alpha_{w}=I_{w} /\left(\mathrm{FR} \times C_{w}\right)
$$

where $\alpha_{w}$ is the absorption efficiency from the dissolved phase (\%), and $C_{w}$ is the metal concentration in the dissolved phase $\left(\mu \mathrm{gl}^{-1}\right)$.

The calculated $\alpha_{w}$ of $\operatorname{Cr}$ (VI) and Se(IV) was 0.03 and $0.018 \%$, respectively, and was independent of the mussel's body size. For $\mathrm{Cd}$ and $\mathrm{Zn}$, the calculated $\alpha_{w}$ was $0.15 \mathrm{~W}^{-0.219}(\%)$ and $0.34 \mathrm{~W}^{-0.119}(\%)$, respectively, and was inversely dependent on the body size.

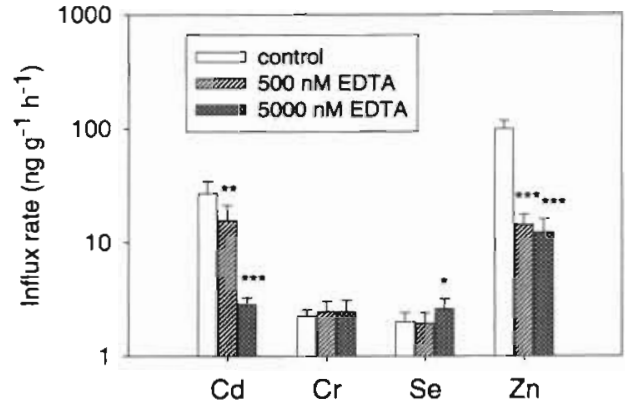

Fig. 8. Septifer virgatus. Metal influx rates in mussels exposed to different concentrations of EDTA. Mean \pm SD $(n=8)$. Differences of metal influx rate from controls are statistically significant ( $t$-test) at various $p$ levels as follows: $p<0.05$; $\cdots p<0.01 ; \cdots p<0.001$

\section{DISCUSSION}

\section{Comparison of metal uptake rates}

Our studies demonstrated that metal uptake proceeded linearly over time in mussels, consistent with previous studies in other bivalves (e.g. George \& Coombs 1977, Bjerregaard et al. 1985). Mussels may therefore require a long period of exposure to reach equilibrium with ambient metals. A bioconcentration factor (with an equilibrium assumption) quantified in the laboratory conditions may not be realistic for predicting metal concentration in animals in real environments where equilibria may be more often achieved than in laboratory studies. More recent studies tend to quantify the metal unidirectional flux rate using a short-term exposure, primarily because the chemical and physiological conditions are comparatively easy to manipulate (Luoma et al. 1992, Roesijadi \& Unger 1993, Vercauteren \& Blust 1996, Wang et al. 1996). This 'kinetic' approach may be more useful in understanding metal bioaccumulation than the 'equilibrium' approach involved with a long-term exposure (Luoma \& Fisher 1997). The bioconcentration factor can then be predicted based on the kinetic measurements of the rate constants of uptake and efflux.

The uptake rate constant is an important physiological parameter quantifying metal bioavailability from the dissolved phase. Mechanistically, the uptake rate constant is a function of the mussel's filtration rate and the absorption efficiency of metals (defined as the efficiency at which a metal can be absorbed from a certain volume of pumped water). The absorption efficiency is analogous to the assimilation efficiency from an ingested food source, which has been extensively studied in bivalves (reviewed in Wang \& Fisher in 1999a). A complete understanding of metal bioaccumulation also requires measurements of uptake rate constant (or 


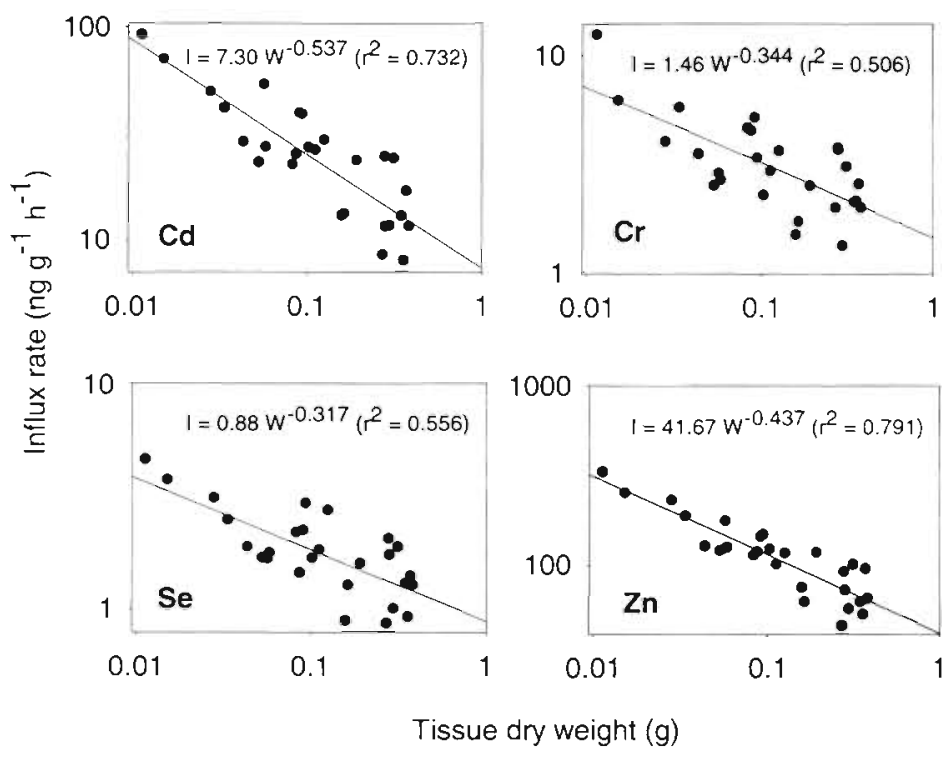

Fig. 9. Septifer virgatus. Metal influx rates in mussels (ng $\mathrm{g}^{-1}$ dry wt $\mathrm{h}^{-1}$ ) in relation to tissue dry weight

absorption efficiency) from the dissolved phase. In this study, the uptake rate constant was independent of the metal concentration in the dissolved phase. The power coefficient describing the relationship between the influx rate and metal concentration in the dissolved phase was close to 1.0 , similar to findings in other marine bivalves (Wang et al. 1996, 1997, Lee et al. 1998). A coefficient $<1$ would imply that the uptake rate constant is inversely dependent on metal concentration in the dissolved phase.

Considerable variation of the uptake rate constant is found among different metals. In Septifer virgatus, the highest uptake rate constant was recorded for $\mathrm{Zn}$, followed by $\mathrm{Cd}>\mathrm{Cr}$ (VI) > Se(IV), consistent with studies in other invertebrates (Bryan 1984, Wang et al. 1996 , Lee et al. 1998, Wang \& Fisher 1998). For example, Wang et al. (1996) showed that the metal uptake rate constant in the mussel Mytilus edulis is the highest for $\mathrm{Ag}$, followed by $\mathrm{Zn}>\mathrm{Cd}>\mathrm{Co}, \mathrm{Am}>\mathrm{Se}$. In general, metals that prefer to bind with SH-containing ligands have much higher uptake rates than metals that prefer to bind with $\mathrm{O}$ - or $\mathrm{N}$-containing compounds. There are some exceptions to this general rule. For example, methylmercury $\left(\mathrm{CH}_{3} \mathrm{Hg}\right)$ has the highest uptake rate in mussels and polychaetes among any metals studied (Gagnon \& Fisher 1997, Wang et al. 1998), presumably due to its extremely lipophillic nature, which allows its free passage across the lipid bilayer.

The higher uptake of $\mathrm{Cd}$ and $\mathrm{Zn}$ than anionic $\mathrm{Cr}$ (VI) and Se(IV) in Septifer virgatus may simply be due to their facilitated transport across the biological membrane. N-ethylmaleimide, which can specifically block the proteins and small molecular SH-containing com- pounds (e.g. glutathione) (Bobilya et al. 1992), reduced the uptake of $\mathrm{Cd}$ and $\mathrm{Zn}$ by 34 to $36 \%$, indicating that their transport is mediated by proteins or small molecular SH-containing compounds. Carpene \& George (1981) propose that Cd uptake in mussel Mytilus edulis gills is by diffusion and facilitated by intracellular binding and sequestration. Similarly, Wang \& Fisher (1999b) show that N-ethylmaleimide inhibits the uptake of $\mathrm{Ag}$ (by 88\%), $\mathrm{Zn}$ (by $85 \%$ ), and Cd (by $69 \%$ ) in $M$. edulis. Our present study also demonstrated that $\mathrm{Cd}$ and $\mathrm{Zn}$ uptake in the black mussels was coupled, further implying that these metals are presumably transported via the same pathway. No previous study has reported a tight coupling between $\mathrm{Cd}$ and $\mathrm{Zn}$ uptake in aquatic invertebrates. Interaction between $\mathrm{Cd}$ and $\mathrm{Zn}$ is, however, not observed (Wang \& Fisher 1999b). Facilitated transport may thus greatly enhance metal transport across the biological membrane. The uptake rates of metals that are primarily transported by passive diffusion (e.g. Co in $M$. edulis, Wang \& Fisher 1999b) are generally lower than metals transported by facilitated processes (e.g. Ag, Cd, Zn, Hg) (Wang et al. 1996). A lower uptake rate may result in less contribution of metals from the dissolved phase to the overall accumulation in the animals.

Our data suggested that Ca channel was not involved in the uptake of all 4 trace elements in Septifer virgatus because their uptake was not affected by the Ca channel blockers verapamil and lanthanum. Verapamil is a blocker of the full-spectrum Ca channel, including the voltage-sensitive and receptor-operated $\mathrm{Ca}$ channel (Guerrero \& Martin 1984, Hughes et al. 1986). In a recent study, Wang \& Fisher (1999b) demonstrate that verapamil significantly inhibit the uptake of $\mathrm{Ag}$ and $\mathrm{Zn}$ in Mytilus edulis, but not in the clam Macoma balthica. Lanthanum has been shown to effectively block $\mathrm{Cd}$

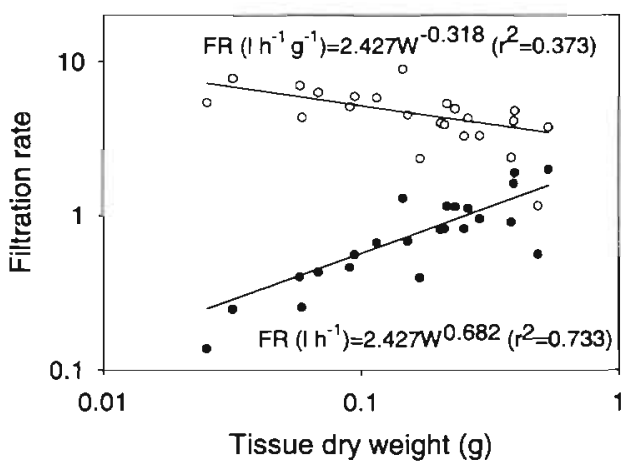

Fig. 10. Septifer virgatus. The filtration rate (FR) and weightspecific filtration rate of mussels in relation to tissue dry weight (W) 
influx through the $\mathrm{Ca}$ channel in crab and fish gills (Verbost et al. 1987, 1989, Lucu \& Obersnel 1996). Consequently, the involvement of the $\mathrm{Ca}$ channel in metal transport appears to be dependent on specific metals, animals, and environmental conditions.

The mechanism of transport of Cr(VI) and Se(IV) in aquatic invertebrates is not well understood, and it is unlikely that these anionic metals are transported by a facilitated process. Simkiss \& Taylor (1995) suggested that the transport of $\mathrm{Cr}$ and Se may occur via anion. channels which transport phosphate or sulfate; however, there is little supporting evidence. For example, Riedel (1985) finds that Cr(VI) toxicity in the diatom Thalassiosira pseudonana is a function of Cr to sulfate ratio in seawater. In mussels, it is likely that $\mathrm{Cr}$ (VI) and Se(IV) are transported via different channel systems because their uptake rates are decoupled. The 5.2-fold increase in Se(IV) uptake in mussels exposed to lanthanum is consistent with findings in Mytilus edulis and Macoma balthica (Wang \& Fisher 1999b). Lanthanum can greatly stimulate the influx of $\mathrm{Cl}^{-}$and $\mathrm{Na}^{+}$in goldfish (Eddy \& Bath 1979).

Lee et al. (1998) recently suggested that despite the inter-specific difference in metal uptake rate (Table 1), the relative magnitude of uptake of different metals is comparable among the 3 bivalves they examined (Mytilus edulis, Macoma balthica, and Potamocorbula amurensis). For example, the relative ratio of metal uptake rate constant for $\mathrm{Zn}: \mathrm{Cd}: \mathrm{Cr}(\mathrm{VI}): \mathrm{Se}(\mathrm{IV})$ is about $1:(0.29$ to 0.35$):(0.06$ to 0.10$):(0.03$ to 0.08$)$. In Septifer virgatus, the relative ratio of metal uptake rate constant for $\mathrm{Zn}: \mathrm{Cd}: \mathrm{Cr}(\mathrm{VI}): \mathrm{Se}(\mathrm{IV})$ is 1:0.62:0.18:0.07. The difference in the uptake rate between $\mathrm{Cd}$ and $\mathrm{Zn}$ or between Cr(VI) and $\mathrm{Zn}$ is smaller in $S$. virgatus than in other bivalves. The relative transport of metals in $S$. virgatus may therefore be different from the other 3 bivalves.

With the exception of $\mathrm{Zn}$, the uptake rate constants of metals in Septifer virgatus are only marginally lower (12 to $22 \%$ ) than those in Mytilus edulis, and are much higher than those in Macoma balthica and Potamocor-

Table 1 Comparison of the uptake rate constants of metals $\left(\mathrm{lg}^{-1} \mathrm{~d}^{-1}\right)$ among marine bivalves

\begin{tabular}{|c|c|c|c|c|}
\hline Bivalve & $\mathrm{Cd}$ & $\mathrm{Cr}(\mathrm{VI})$ & $\operatorname{Se}(I V)$ & $\mathrm{Zn}$ \\
\hline Mytilus edulis & $0.365^{a}$ & $0.100^{b}$ & $0.035^{\circ}$ & $1.044^{\circ}$ \\
\hline Macoma balthica & $0.032^{\mathrm{c}}$ & $0.006^{\mathrm{c}}$ & $0.007^{d}$ & $0.091^{\circ}$ \\
\hline $\begin{array}{l}\text { Potamocorbula } \\
\text { amurensis }\end{array}$ & $0.125^{c}$ & $0.028^{c}$ & & $0.425^{\circ}$ \\
\hline Septifer virgatus & $0.286^{\mathrm{e}}$ & $0.085^{\mathrm{e}}$ & $0.031^{\circledR}$ & $0.460^{\mathrm{e}}$ \\
\hline
\end{tabular}

bula amurensis (Table 1). A better understanding of metal uptake is the measurements of absorption efficiency by calibrating the inter-specific difference in filtration rate. In our study, the calculated absorption efficiency of $\mathrm{Cr}(\mathrm{VI})$ and Se(IV) was 0.03 and $0.02 \%$, respectively, and was independent of the mussel's body size. Absorption efficiencies of $\mathrm{Cd}$ and $\mathrm{Zn}$ were inversely related to the mussel's body size. For a typical body size of 0.1 to $0.2 \mathrm{~g}$ (dry tissue weight) used in this study, the absorption efficiency can be calculated to be 0.21 to $0.25 \%$ for $\mathrm{Cd}$ and 0.41 to $0.45 \%$ for $\mathrm{Zn}$, which are comparable to the measurements in $M$. edulis $(0.24 \%$ for $\mathrm{Cd}$, and $0.48 \%$ for $\mathrm{Zn}$ ), but are 2.4 to 3.0 times higher than in $M$. balthica (Wang \& Fisher 1999b). The calculated absorption efficiencies of Se(IV) are also comparable among the 3 bivalves $(M$. edulis, M. balthica, and S. virgatus, Wang \& Fisher 1999b, present study). Thus, variation in the filtration rate is responsible for the difference in Se uptake rate among bivalves, but not between mussels and clams for metals such as $\mathrm{Cd}$ and $\mathrm{Zn}$ that appear to be taken up by facilitated transport. Clearly, other factors such as the quantity and type of binding sites may additionally be responsible for the inter-specific difference in metal uptake rates.

Few studies address the effects of various environmental and biological conditions on metal absorption efficiency. Among these factors, metal concentrations in the dissolved phase, metal speciation, the animal's filtration rate and body size are of particular concern. Despite the fact that the absorption efficiency is generally more than 1 order of magnitude lower than the assimilation efficiency from the food source, dissolved uptake can potentially become an important source for the overall metal accumulation in marine bivalves due to the large volume of water that the animals can filter. For example, Wang et al. (1996) calculate that $>50 \%$ of $\mathrm{Cd}$ in Mytilus edulis arises from uptake from the dissolved phase.

\section{Effects of salinity and size on metal uptake}

Metal uptake in Septifer virgatus increased with a decrease in salinity, which is comparable to many studies on other bivalves (Phillips 1976, Jackim et al. 1977. Fischer 1986, Wang et al. 1996, Lee et al. 1998). For example, the influx rates of $\mathrm{Cd}, \mathrm{Se}$, and $\mathrm{Zn}$ in mussel Mytilus edulis increase by 1.5 to 1.6 times with a decrease of salinity from 34 to 15 ppt (Wang et al. 1996). The influx rate of $\mathrm{Cr}$ (VI) in $M$. edulis remains relatively constant between 35 and 20 ppt, but then increases by 4.2 times when the salinity is further reduced down to $15 \mathrm{ppt}$ (Wang et al. 1997). Uptake of $\mathrm{Cd}$ in the 2 clams Macoma balthica and Potamocorbula 
amurensis increases by 4 to 6 times with a decrease in salinity from 30 to $5 \mathrm{ppt}$, whereas uptake of $\mathrm{Zn}$ is not affected by a change in salinity (Lee et al. 1998). In $S$. virgatus, a linear negative relationship between uptake and salinity was found. The degrees to which all 4 metals are affected by decreasing salinity appear to be similar

Several mechanisms have been proposed to explain the underlying salinity effects which are highly dependent on the different animals and metals (Wright 1995). Both the chemical change (e.g. free metal ion concentration, ambient calcium concentration, and activity coefficient) and biological change (e.g. filtration rate, membrane permeability) associated with variation in salinity are presumably responsible for the underlying effects. There is no generic model to incorporate all animals and metals.

Free metal ion concentration clearly determines the uptake of $\mathrm{Cd}$ and $\mathrm{Zn}$ in the mussels. In the presence of the strong chelator EDTA at concentrations of 0.5 and $5 \mu \mathrm{M}, \mathrm{Cd}$ uptake decreased by 42 and $89 \%$ and $\mathrm{Zn}$ uptake decreased by 86 and $88 \%$. The calculated free ion concentrations of Cd and Zn (using the MINEQL program) decreased by 84.5 and $98.5 \%$ for Cd and 96.3 and $99.6 \%$ for $\mathrm{Zn}$ at 0.5 and $5 \mu \mathrm{M}$ EDTA, respectively, indicating that the free ion is presumably the dominant species available to the mussels ( $\mathrm{J}$ Reinfelder pers. comm.). With a decrease of salinity from 34 to $15 \mathrm{ppt}$, the free ion $\mathrm{Cd}$ concentration would increase by 3 times (from $9 \%$ of total Cd concentration to about $3 \%$ of total Cd concentration), whereas $\mathrm{Zn}$ free ion concentration increases by only $25 \%$ within this salinity range (Mantoura et al. 1978, Sunda et al. 1978). These calculations, however, only assume that $\mathrm{Cd}$ and $\mathrm{Zn}$ are complexed by inorganic ligands, although in marine environments the majority of $\mathrm{Cd}$ and $\mathrm{Zn}$ may be complexed by organic ligands (Bruland 1989, 1992). Furthermore, the anionic Se(IV) and Cr(VI) speciation is expected to be relatively independent of the salinity variation, but their uptake was equally influenced by reducing salinity. Thus, free ion speciation is unlikely to be responsible for the underlying salinity effects (with the exception of $\mathrm{Cd}$ ), at least within the salinity range examined in this study. Similarly, Wright \& Zamuda (1987) suggest that the salinity effects on Cu uptake in the oyster Crassostrea virginica and the clam Mya arenaria are not related to the $\mathrm{Cu}$ free ion activity.

Another possible mechanism is the change in ambient Ca concentration which has been shown to reduce Cd uptake in crabs and rainbow trout because of its competition with $\mathrm{Cd}$ through the same Ca transport system (Wright 1977, Verbost et al. 1989, Lucu \& Obersnel 1996). Ca may affect the membrane permeability or compete with the biological uptake sites for metals that can be transported by the Ca channel. However, variation of $\mathrm{Ca}$ concentration was not responsible for the varying influx rate in Septifer virgatus, consistent with findings in the mussel Mytilus edulis and the clam Macoma balthica (Wang \& Fisher 1999b). Bjerregaard \& Depledge (1994) conclude that change in the Ca concentration accounts for $72 \%$ of the salinity effect on Cd accumulation in the gastropod Littorina littorea, but has no effect on Cd accumulation in the mussel $M$. edulis. In marine bivalves, most $\mathrm{Ca}$ may simply be taken up by passive diffusion rather than by $\mathrm{Ca}$ channel because of the high ambient Ca concentration (Rainbow 1997). Ca uptake in $M$. edulis is only marginally inhibited by $\mathrm{Ca}$ channel blockers such as verapamil and lanthanum (Wang \& Fisher 1999b). Ca has also been shown to have no appreciable effect on $\mathrm{Zn}$ uptake in aquatic invertebrates (Nugegoda \& Rainbow 1989a,b, Bervoets et al. 1996).

The effects of salinity on metal uptake in Septifer virgatus therefore remain unexplained. In this study, we did not quantify the filtration rate of mussels acclimated to different salinities for $2 \mathrm{wk}$, but it is noted that acclimation can be achieved within $8 \mathrm{~d}$ in Mytilus edulis (Widdows 1985). Wang et al. (1996) conclude that the filtration rate is unlikely to explain the salinity effect in $M$. edulis. Because all 4 metals are affected to a similar degree by salinity change, there must be a common mechanism to account for such an effect. One possible explanation is the change in osmolarity, but this remains to be examined further. For example, George et al. (1978) indicate that a decrease in osmolarity with decreasing salinity results in an increase in $\mathrm{Cd}$ uptake in mussels. They further show that $\mathrm{Cd}$ uptake is independent of the salinity over a range of 15 to 35 ppt when the osmolarity is held constant. However, Zn uptake in the decapod Palaemon elegans and Cd uptake in the brine shrimp Artemia franciscana are independent of the osmolarity (Nugegoda \& Rainbow 1989b, Blust et al. 1992).

Our studies demonstrate that the metal uptake rate is dependent on the mussel's body size, consistent with previous studies on other invertebrates (Newman \& Mitz 1988, Wang \& Fisher 1997b, Lee et al. 1998). Furthermore, the allometric coefficients of the power function of the influx rate with body size were -0.32 to -0.34 for Se(IV) and Cr(VI), comparable to the allometric coefficient for the filtration rate $(-0.32)$. These data strongly imply that the allometry of Se(IV) and Cr(VI) uptake and the mussel's filtration activity are controlled by the same process. Gilek et al (1996) show that the allometric coefficient of the gill surface area in Mytilus edulis is -0.32 . If this value is applicable to Septifer virgatus, it is likely that the allometric change of gill surface area determines both the filtration activity and Se(VI) and Cr(IV) uptake in mussels. For Cd and $\mathrm{Zn}$, the allometric coefficients $(-0.44$ to -0.54$)$ 
were higher than that for mussel's filtration rate, and their allometric uptake may also be controlled by other mechanisms such as the ligands available for binding with these SH-seeking metals. Similarly, Wang \& Fisher (1997b) find that the allometric coefficient in $M$. edulis is -0.56 for $\mathrm{Cd}_{1}-0.29$ for Se(IV), and -0.57 for $\mathrm{Zn}$, although only 3 body sizes were examined in that study. Lee et al. (1998) report that the allometric coefficients in both Macoma balthica and Potamocorbula amurensis are -0.48 to -0.49 for $\mathrm{Cd}_{1}-0.21$ to -0.25 for $\mathrm{Cr}(\mathrm{VI})$, and -0.46 to -0.51 for $\mathrm{Zn}$. These studies consistently show that the allometric coefficients are much higher for $\mathrm{Cd}$ and $\mathrm{Zn}$ than for Se(IV) and $\mathrm{Cr}(\mathrm{VI})$. Because metal transport across the biological membrane is primarily a passive process (e.g. diffusion or facilitated transport) and does not require energy expenditure (Simkiss \& Taylor 1989, 1995, Wang \& Fisher 1999b), it is unlikely that the allometry of metabolic activity of mussels (e.g. -0.35 , Widdows 1978) controls the allometry of metal uptake, even though they are in general comparable.

Because the allometric scalings of Se(IV) and $\mathrm{Cr}$ (VI) uptake and the mussel's filtration rate are comparable, it is possible to calculate the influx rates of these metals based on the measurements of the mussel's filtration activity. Conversely, uptake of Se(IV) and $\mathrm{Cr}$ (VI) can be used to indicate the filtration activity of the mussels. However, these influx rates are measured at a specific concentration [ $38 \mathrm{nM}$ for $\mathrm{Cr}(\mathrm{VI})$, and $27 \mathrm{nM}$ for $\mathrm{Se}(\mathrm{IV})]$ and can only be considered 'conditional'.

In conclusion, our study demonstrates that $\mathrm{Cd}$ and $\mathrm{Zn}$ in the mussel Septifer virgatus are primarily transported by a facilitated process via binding with $\mathrm{SH}_{-}$ containing ligands. Their uptake follows the same transport pathway and is different from $\mathrm{Cr}$ (VI) and $\mathrm{Se}(\mathrm{IV})$, which may be transported via ionic channels or simple passive diffusion. The $\mathrm{Ca}$ channel is not involved in the transport of $\mathrm{Cd}, \mathrm{Cr}, \mathrm{Se}$, and $\mathrm{Zn}$. Metal uptake in mussels increases proportionally with an increase in the ambient concentration of the metal and a decrease in salinity, but it is independent of the ambient $\mathrm{Ca}$ concentration. Although free ions of $\mathrm{Cd}$ and $\mathrm{Zn}$ are the most bioavailable species to the mussels, changes in metal speciation are unlikely to be responsible for the underlying salinity effect on metal uptake. Our results also show that the allometry of Se(IV) and Cr(VI) uptake is simply controlled by the allometry of the gill surface area or filtration activity. Their uptake may be predicted based on the measurement of the mussel's filtration rate. Other allometricdependent processes in addition to the gill surface area control the allometric uptake of $\mathrm{Cd}$ and $\mathrm{Zn}$. Our study also highlights the importance of metal absorption efficiency in understanding the bioavailability of metals from the dissolved phase to marine bivalves.
Acknowledgements. We are grateful for the anonymous reviewers for their helpful comments. This study was supported by a DAG and a RGC grant (HKUST6137/99M), and the start-up fund to W.X.W.

\section{LITERATURE CITED}

Abu-Saba KE, Flegal AR (1995) Chromium in San Francisco Bay: superposition of geochemical processes causes complex spatial distributions of redox species. Mar Chem 49: $189-199$

Bervoets L, Blust R, Verheyen R (1996) Uptake of zinc by the midge larvae Chironomus riparius at different salinities: role of speciation, acclimation, and Ca. Environ Toxicol Chem 15:1423-1428

Bjerregaard P, Depledge MH (1994) Cadmium accumulation in Littorina littorea, Mytilus edulis and Carcinus maenas: the influence of salinity and $\mathrm{Ca}$ ion concentrations. Mar Biol 119:385-395

Bjerregaard P, Topçuoğlu S, Fisher NS, Fowler SW (1985) Biokinetics of americium and plutonium in the mussel Mytilus edulis. Mar Ecol Prog Ser 21:99-111

Blust R, Kockelbergh E, Baillieul M (1992) Effect of salinity on the uptake of cadmium by the brine shrimp Artemia franciscana. Mar Ecol Prog Ser 84:245-254

Bobilya D, Briske-Anderson M, Reeves PG (1992) Zinc transport into endothelial cells is a facilitated process. J Cell Physiol 151:1-7

Borchardt T, Burchert S, Hablizel H, Karbe L, Zeitner R (1988) Trace metal concentrations in mussels: comparison between estuarine, coastal and offshore regions in the southeastern North Sea from 1983 to 1986. Mar Ecol Prog Ser $42: 17-31$.

Bruland KW (1983) Trace elements in sea-water. In: Riley JP, Chester R (eds) Chemical aceanography, Vol 8. Academic Press, London, p 157-200

Bruland KW (1989) Complexation of zinc by natural organic ligands in the central North Pacific. Limnol Oceanogr 34: $269-285$

Bruland KW (1992) Complexation of cadmium by natural organic ligands in the central North Pacific. Limnol Oceanogr 37:1008-1017

Bryan GW (1984) Pollution due to heavy metals and their compounds. In: Kinne O (ed) Marine ecology, Vol 5. John Wiley \& Sons, Chichester, p 1289-1430

Campbell PGC (1995) A critique of the free-ion activity model. In: Tessier A, Turner DR (eds) Metal speciation and bioavailability in aquatic systems. John Wiley \& Sons, Chichester, p 45-102

Carpene E, George SG (1981) Absorption of cadmium by gills of Mytilus edulis (L.). Mol Physiol 1:23-34

Cutter GA (1989) The estuarine behavior of selenium in San Francisco Bay. Estuar Coast Shelf Sci 28:13-34

Eddy FB, Bath RN (1979) Effects of lanthanum on sodium and chloride fluxes in the goldfish Carassius auratus. J Comp Physiol 129:145-149

Fischer $H(1986)$ Influence of temperature, salinity, and oxygen on the cadmium balance of mussels Mytilus edulis. Mar Ecol Prog Ser 32:265-278

Fisher NS, Reinfelder JR (1995) The trophic transfer of metals in marine systems. In: Tessier A, Turner DR (eds) Metal speciation and bioavailability in aquatic systems. John Wiley \& Sons, Chichester, p 363-406

Flegal AR, Smith GJ, Gill GA, Sañudo-Wilhelmy S, Anderson LCD (1991) Dissolved trace element cycles in San Francisco Bay estuary. Mar. Chem 36:329-363 
Gagnon C, Fisher NS (1997) Bioavailability of sedimentbound methyl and inorganic mercury to a marine bivalve. Environ Sci Technol 31:147-156

George SG, Coombs TL (1977) The effects of chelating agents on the uptake and accumulation of cadmium by Mytilus edulis. Mar Biol 39:261-268

George SG, Carpene E, Coombs TL (1978) The effects of salinity on the uptake of cadmium by the common mussel, Mytilus edulis (L.). In: McLusky DS, Berry AJ (eds) Physiology and behavior of marine organisms. Pergamon Press, Oxford, p 189-193

Gilek M, Björk M, Näf C (1996) Influence of body size on the uptake, depuration, and bioaccumulation of polychlorinated biphenyl congeners by Baltic Sea blue mussels, Mytilus edulis. Mar Biol 125:499-510

Guerrero JR, Martin SS (1984) Verapamil, full spectrum Ca channel blocking agent: an overview. Med Res Rev 4 : $87-109$

Hughes BP, Milton SE, Barritt GJ, Auld AM (1986) Studies with verapamil and nifedipine provide evidence for the presence in the liver cell plasma membrane of two types of $\mathrm{Ca}^{2+}$ inflow transporter which are dissimilar to potentialoperated $\mathrm{Ca}^{2+}$ channels. Biochem Pharmacol 35:3045-3052

Jackim E, Morrison G, Steele R (1977) Effects of environmental factors on radiocadmium uptake by four species of marine bivalves. Mar Biol 40:303-308

Langston WJ, Spence SK (1995) Biological factors involved in metal concentrations observed in aquatic organisms. In: Tessier A, Turner DR (eds) Metal speciation and bioavailability in aquatic systems. John Wiley $\&$ Sons, Chichester, p 407-478

Lee BG, Wallace WG, Luoma SN (1998) Uptake and loss kinetics of $\mathrm{Cd}, \mathrm{Cr}$ and $\mathrm{Zn}$ in the bivalves Potamocorbula amurensis and Macoma balthica: effects of size and salinity. Mar Ecol Prog Ser 175:177-189

Lucu C, Obersnel V (1996) Cadmium influx across isolated Carcinus gill epithelium: interaction of lanthanum and Ca with cadmium influxes. J Comp Physiol B 166:184-189

Luoma SN, Fisher NS (1997) Uncertainties in assessing contaminant exposure from sediments. In: Ingersoll CG, Dillon T, Biddinger GR (eds) Ecological risk assessment of contaminated sediments. SETAC Spec Publ Series, Pensacola, FL p 211-237

Luoma SN, Johns C, Fisher NS, Steinberg NS, Oremland RS, Reinfelder JR (1992) Determination of selenium bioavailability to a benthic bivalve from particulate and solute pathways. Environ Sci Technol 26:485-492

Mantoura RFC, Dickson A, Riley JP (1978) The complexation of metals with humic materials in natural waters. Estuar Coast Mar Sci 6:387-408

Newman MC, Mitz SV (1988) Size dependence of zinc elimination and uptake from water by mosquitofish Gambusia affinis (Baird and Girard). Aquat Toxicol 12:17-32

Nugegoda D, Rainbow PS (1989a) Effects of salinity changes on zinc uptake and regulation by the decapod crustaceans Palaemon elegans and Palaemonetes varians. Mar Ecol Prog Ser 51:57-75

Nugegoda D, Rainbow PS (1989b) Salinity, osmolarity and zinc uptake in Palaemon elegans (Crustacea: Decapoda). Mar Ecol Prog Ser 55:149-157

Phillips DJH (1976) The common mussels Mytilus edulis as an indicator of pollution by zinc, cadmium, lead and copper. 1 . Effects of environmental variables on uptake of metals. Mar Biol 38:59-69

Phillips DJH, Rainbow PS (1993) Biomonitoring of aquatic trace contaminants. Chapman and Hall, London

Phillps DJH, Yim WWS (1981) A comparative evaluation of oysters, mussels and sediments as indicators of trace metals in Hong Kong Waters. Mar Ecol Prog Ser 6:285-293

Rainbow PS (1997) Ecophysiology of trace metal uptake in crustaceans. Estuar Coast Shelf Sci 44:169-175

Reinfelder JR, Fisher NS, Luoma SN, Nichols JW, Wang WX (1998) Trace element trophic transfer in aquatic organisms: a critique of the kinetic model approach. Sci Total Environ 219:117-135

Riedel GF (1985) The relationship between chromium(VI) uptake, sulfate uptake and chromium(VI) toxicity to the estuarine diatom Thalassiosira pseudonana. Aquat Toxicol 7:191-204

Riedel GF, Sanders JG, Gilmour CC (1996) Uptake, transformation, and impact of selenium in freshwater phytoplankton and bacterioplankton communities. Aquat Microb Ecol 11:43-51

Roditi H, Fisher NS (in press) Rates and routes of trace element uptake in zebra mussels. Limnol Oceanogr

Roesijadi G, Unger ME (1993) Cadmium uptake in gills of the mollusc Crassostrea virginica and inhibition by Ca channel blockers. Aquat Toxicol 24:195-206

Simkiss K, Taylor MG (1989) Metal fluxes across the membrane of aquatic organisms. Rev Aquat Sci 1:173-188

Simkiss K, Taylor MG (1995) Transport of metals across membranes. In: Tessier A, Turner DR (eds) Metal speciation and bioavailability in aquatic systems. John Wiley \& Sons, Chichester, p 2-44

Sunda WG, Engel DW, Thuotte RM (1978) Effect of chemical speciation on toxicity of cadmium to grass shrimp, Palaemonetes pugio: importance of free cadmium ion. Environ Sci Technol 12:409-413

Verbost PM, Flik G, Lock RAC, Wendelaar Bonga SE (1987) Cadmium inhibition of $\mathrm{Ca}^{2+}$ uptake in rainbow trout gills. Am J Physiol 253:R216-221

Verbost PM, Van Rooij J, Flik G, Lock RAC, Wendelaar Bonga SE (1989) The movement of cadmium through freshwater trout branchial epithelium and its interference with $\mathrm{Ca}$ transport. J Exp Biol 145:185-197

Vercauteren K, Blust R (1996) Bioavailability of dissolved zinc to the common mussel Mytilus edulis in complexing environments. Mar Ecol Prog Ser 137:123-132

Wang WX, Fisher NS (1997a) Modeling metal bioavailability for marine mussels. Rev Environ Contam Toxicol 151: $39-65$

Wang WX, Fisher NS (1997b) Modeling the influence of body size on trace metal accumulation in the mussel Mytilus edulis. Mar Ecol Prog Ser 161:103-115

Wang WX, Fisher NS (1998) Accumulation of trace elements in a marine copepod. Limnol Oceanogr 43:273-283

Wang WX, Fisher NS (1999a) Assimilation efficiencies of chemical contaminant in aquatic invertebrates: a synthesis. Environ Toxicol Chem 18:2034-2045

Wang WX, Fisher NS (1999b) Effects of calcium and metabolic inhibitors on trace element uptake in two marine bivalves. J Exp Mar Biol Ecol 236:149-164

Wang WX. Fisher NS (in press) Delineating metal exposure pathways in marine invertebrates. Sci Total Environ

Wang WX, Fisher NS, Luoma SN (1996) Kinetic determinations of trace element bioaccumulation in the mussel Mytilus edulis. Mar Ecol Prog Ser 140:91-113

Wang WX, Griscom SB, Fisher NS (1997) Bioavailability of $\mathrm{Cr}(\mathrm{III})$ and $\mathrm{Cr}$ (VI) to marine mussels from solute and particulate pathways. Environ Sci Technol 31:603-611

Wang WX, Stupakoff 1, Gagnon C, Fisher NS (1998) Bioavailability of inorganic and methylmercury to a marine deposit-feeding polychaete. Environ Sci Technol 32: $2564-2571$ 
Ward JE, Targett NM (1989) Influence of marine microalgal metabolites on the feeding behavior of the blue mussel Mytilus edulis. Mar Biol 101:313-321

Widdows J (1978) Combined effects of body size, food concentration and season on the physiology of Mytilus edulis. J Mar Biol Assoc UK 58:109-124

Widdows J (1985) The effects of fluctuating and abrupt changes in salinity on the performance of Mytilus edulis. In: Gray JS, Christiansen ME (eds) Marine biology of polar regions and effects of stress on marine organisms. John Wiley \& Sons, New York, p 555-566

Editorial responsibility: Otto Kinne (Editor),

Oldendorf/Luhe, Germany
Widdows J, Nasci C, Fossato VU (1997) Effects of pollution on the scope for growth of mussels (Mytilus galloprovincialis) from the Venice Lagoon, Italy. Mar Environ Res 43: $69-79$

Wright DA (1977) The effect of Ca on cadmium uptake by the shore crab Carcinus maenas. J Exp Biol 67:163-173

Wright DA (1995) Trace metal and major ion interactions in aquatic animals. Mar Pollut Bull 31:8-18

Wright DA, Zamuda CD (1987) Copper accumulation by two bivalve molluscs: salinity effect is independent of cupric ion activity. Mar Environ Res 23:1-14

Submitted: January 26, 1999; Accepted: June 1, 1999 Proofs received from author(s): August 27, 1999 